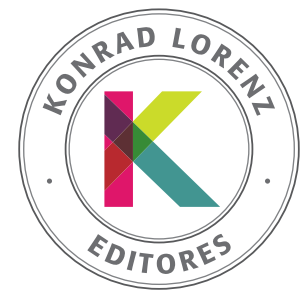

\title{
Revista Latinoamericana de Psicología
}

http://revistalatinoamericanadepsicologia.konradlorenz.edu.co/

\section{ORIGINAL}

\section{Human resource practices and employee wellbeing from a gender perspective: The role of organizational justice}

\author{
Beatriz Sora ${ }^{a, *}$, Amparo Caballer ${ }^{b}$, M. Esther García-Buades ${ }^{b}$
}

a Universitat Rovira $i$ Virgili, Spain

${ }^{b}$ University of Valencia, Spain

c University of the Balearic Islands, Spain

Received 6 May 2020; accepted 8 March 2021

\section{KEYWORDS HR practices, organizational justice, well-being, gender}

\begin{abstract}
Introduction/objective: HR practices have been widely studied in the literature. However, critical research gaps remain unexplored. Little attention has been paid to the relationship between HR practices and well-being, or the mechanisms that explain the effect of HR on employees' wellbeing, and the role of gender in this relationship. Hence, this study aims to examine the relationship between HR practices and well-being (eudemonic and hedonic) through organizational justice, taking into account gender. Method: A convenience sampling technique was used in a correlational design. The sample was composed of 1647 employees from 42 Spanish organizations. Our measures were HR practices, organizational justice, and hedonic and eudemonic wellbeing. Multi-group structural equation models were computed. Results: The results supported our hypothesis, which mainly stated that (1) organizational justice (distributive, procedural and interactional justice) mediated the relationship between HR practices and eudemonic and hedonic well-being; (2) there were differences between men and women in this mediation. Conclusions: Human resource practices and organizational justice offer tools to HR managers in order to maintain and improve employees' well-being levels within their organizations.
\end{abstract}

(c) 2021 Fundación Universitaria Konrad Lorenz. This is an open access article under the CC BYNC-ND license (http://creativecommons.org/licenses/by-nc-nd/4.0/).

Prácticas de recursos humanos y bienestar de los empleados desde una perspectiva de género: el papel de la justicia organizacional

Resumen Introducción/objetivo: Las prácticas de recursos humanos (RRHH) han sido ampliamente estudiadas en la literatura. Sin embargo, existen importantes carencias de investigación al respecto. Por ejemplo, se ha prestado poca atención a la relación entre las prácticas de RRHH y el bienestar, al mecanismo que explica el efecto de los RRHH en los empleados, y se ha pasado por alto el papel del género en las prácticas de RRHH. Por tanto, este estudio se dirige a examinar la relación entre las prácticas de RRHH y el bienestar (eudemónico y hedónico) por medio de la justicia organizacional, teniendo en cuenta el género. Método: Se utilizó un muestreo por conveniencia en un diseño correlacional. La muestra se compuso de 1647

\footnotetext{
* Corresponding author.

E-mail: bsora@uoc.edu
}

https://doi.org/10.14349/rlp.2021.v53.5

0120-0534/@ 2021 Fundación Universitaria Konrad Lorenz. Este es un artículo Open Access bajo la licencia CC BY-NC-ND (http://creativecommons.org/licenses/by-nc-nd/4.0/). 
trabajadores de 42 organizaciones españolas. Los instrumentos utilizados midieron prácticas de RRHH, justicia organizacional, y bienestar hedónico y eudemonico. Se realizaron modelos de ecuaciones estructurales multigrupo. Resultados: Los resultados confirmaron nuestras hipótesis, que afirmaban principalmente que (1) la justicia organizacional (justicia distributiva, de procedimiento e interactiva) mediaba la relación entre las prácticas de RRHH y el bienestar eudemónico y hedónico; (2) hay diferencias entre hombres y mujeres en esta mediación. Conclusiones: Las prácticas de RRHH y la justicia organizacional ofrecen herramientas a los directores de RRHH sobre cómo actuar para mantener y mejorar los niveles de bienestar de los empleados dentro de sus organizaciones.

(C) 2021 Fundación Universitaria Konrad Lorenz. Este es un artículo Open Access bajo la licencia CC BY-NC-ND (http://creativecommons.org/licenses/by-nc-nd/4.0/).

Currently, organizations all over the world have to survive and succeed in a highly dynamic and competitive environment. In this context, employees are considered to be the most important asset given that their effective development and deployment offers a distinctive and non-imitable competitive advantage (Fesharaki \& Sehhat, 2018). Thus, a main organizational task is to manage human resources (HR) effectively. To do so several emerging HR practices are available to guarantee and enhance HR functioning (Guest, 2011; Zhang \& Agarwal, 2009).

Taking into account the vital role of HR within organizations, HR practices have received significant attention by professionals and researchers (Guest, 2011). According to Guest (2017), after years of research, there is finally a clearer understanding of HR practices, most particularly, the strategic role of external and internal fit. However, several authors, including Guest $(2017,2011)$ and Peccei $(2004)$, admit that significant research gaps still remain. For example, while the literature has attempted to understand the mechanisms through which HR practices impact performance (e.g., Jiang et al., 2012), this issue remains unclear. In fact, some authors have labelled this the 'black box' problem in the HR practice-performance relationship (Messersmith et al., 2011; Sun et al., 2007). The focus on performance has implied overlooking other very significant and equally important consequences of HR practices; for instance, employee wellbeing (Guest, 2017). Finally, HR practices produce and reproduce outdated ideals based on gender stereotypes. These gendered norms may determine who gets hired, promoted and rewarded in the workplace (Mastracci \& Arreola, 2016; Perry, 2010). Mastracci and Arreola (2016) have therefore called for further research into gendered organizations, and, particularly, into gendered HR practices, as an issue that still needs clarification.

The above discussion would suggest a need for research in order to address the mechanisms through which HR practices impact, not only performance, but also wellbeing, while taking into account the role of gender in organizations. We examine the role of organizational justice as a potential mediator in the relationship between HR practices and wellbeing, assessing the differences between men and women. According to social exchange theory (Blau, 1964), positive perception of HR practices could determine employees' justice perceptions about the treatment that they receive within their organizations, which in turn may affect their well-being.

\section{Human resource practices and wellbeing}

The neglect of well-being has been criticized from a labour and critical management perspective by professionals and academics who argue that HR practices are designed and used as part of a wider strategy to manage culture and ensure that employees are committed and contribute to organizational performance and functioning (e.g., Legge, 2005; Keenoy \& Anthony, 1992). This criticism is underpinned by the idea that the development and promotion of more advanced high-performance practices by organizations usually leads to an intensification of work and a more systematic exploitation of employees (Landsbergis et al., 1999; Peccei, 2004). In this respect, it has to be conceded that history teaches us that it is unlikely that organizations would design and apply HR practices aimed at promoting employee wellbeing on ethical grounds alone, a fact which has encouraged multiple employment legislation initiatives.

Some studies show that a management strategy directed at organizational performance may be associated with a decrease in employee wellbeing and even performance levels (e.g., Jalalkamali et al., 2016; Kariithi \& Odongo, 2016). A possible explanation is offered by Wright and Nishii (2006) and Khilji and Wang (2006), who suggest that it is vital to take employee perceptions of HR practices into account - of the intentions behind the practices - as this would have a positive impact on employee performance. Employees usually perceive that HR practices shift the balance of advantage towards the employer rather than towards employee outcomes (Guest \& Peccei, 2001). Hence, an alternative and more optimistic perspective on HR practices is largely supported by mainstream scholars, as it is argued that the adoption of progressive HR practices related to job design, training and development, employee involvement, information-sharing, pay and rewards, etc., leads to higher levels of discretion and empowerment for employees and ultimately leads to greater employee wellbeing (Peccei, 2004).

However, the fact that organizations must survive in a competitive environment cannot be overlooked. So, even though employee wellbeing is vital, performance is also crucial to ensure an organization's survival and competitiveness; therefore, it is necessary to adjust the interests of both employers and employees. According to Guest (2017), this is possible by adopting a pluralist perspective framed within the context of the employment relationship and social exchange theory (Blau, 1964). A positive employment relations climate, that offers the basis for partnership 
within organizations, yields mutual benefits for the relevant stakeholders (Guest, 2017; Valizade et al., 2016). In this respect, the social exchange theory (Blau, 1964) states that social exchanges are "voluntary actions" that may be initiated by an organization's treatment of its employees, with the expectation that such treatment will eventually be reciprocated. In fact, "the voluntary actions of individuals are motivated by the returns they are expected to bring from others . . . [with the] exact nature [of the return] never specified in advance but . . . left to the discretion of the one who makes it" (Blau, 1964, pp. 91-92). Hence, employees who perceive evidence in their organization of goodwill and support for (i.e., 'good' HR practices) will not only feel motivated and may even feel obliged to reciprocate with behaviours and attitudes that are beneficial for the organization (Aryee et al., 2002), but will also feel satisfied with their exchange relationship with the organization (Guest, 2017). As such, positive social exchanges can result in mutual benefits for both an organization and its workforce (Gould-Williams \& Davies, 2005). In this vein, Guest (2017) proposed an HR practices model that defines the core elements of HR practices in terms of recruitment and selection, training and development, mentoring and career support, the provision of engaging work, jobs that ensure autonomy and challenge, information provision and feedback, and skill utilization. Finally, Guest (2017) also suggests that all these HR practices are associated with higher levels of wellbeing and a more positive employment relationship, in turn related to positive performance outcomes at the individual and unit levels. In other words, this set of HR practices offers mutual gains for both employers and employees.

Following Guest's (2017) HR practices model and Blau's (1964) social exchange theory, we examine the relationship between HR practices and employee wellbeing. Subjective wellbeing (SWB) refers to people's cognitive and emotional evaluations about their lives, in terms of general satisfaction, mood, completeness and satisfaction with specific domains, such as marriage and work (Diener et al., 2003). In practical terms, SWB refers to people's "evaluations of their lives" (Diener, 2000, p. 34). We understand the concept of wellbeing in terms of its double dimensionality, i.e. hedonic and eudemonic. Hedonic wellbeing has predominated in the literature in the last two decades (Culbertson et al., 2010). One of its most accepted definitions is in terms of the achievement of pleasure and the avoidance of pain (Ryan \& Deci, 2001). Eudemonic wellbeing is defined as "an ideal in the sense of excellence, and perfection toward which one strives, [which] gives meaning and direction to one's life" (p. 1070). It is therefore based on the framework of positive functioning (Peiró et al., 2014). As Peterson et al. (2005, p. 26) pointed out, "uniting eudemonic emphases is the premise that people should develop what is best within themselves and then use these skills and talents in the service of greater goods - including, in particular, the welfare of other people or humankind writ large."

Accordingly, we propose that organizations with 'good' HR practices will transmit to their employees that the organization values their contributions and is concerned for their wellbeing. Thus, employees perceive a reciprocated relationship with their organizations and feel comfortable in this exchange relationship. In sum, when HR practices care for employees in the different dimensions, then employee wellbeing is likely to improve. Our first hypothesis is therefore:

H1. HR practices are positively related to employee hedonic wellbeing $(\mathrm{H} 1 \mathrm{a})$ and eudemonic wellbeing $(\mathrm{H} 1 \mathrm{~b})$.

\section{Organizational justice: A mediating role}

Organizational justice is broadly defined as "the rules and social norms governing how outcomes (e.g., rewards and punishments) should be distributed, the procedures used for making such distribution decisions (as well as other types of decisions), and how people are treated interpersonally" (Folger \& Cropanzano, 1998, p. 13). Hence, it is composed of the following constructs: distributive justice, which emphasizes a proportional distribution of resources according to investments in an exchange relationship (Adams, 1965); procedural justice, defined as "perceived fairness of the process by which outcomes were arrived at" (Cohen-Charash \& Spector, 2001, p. 280); and interactional justice, which reflects the "quality of the interpersonal treatment received by an individual" (Folger \& Cropanzano, 1998, p. 13).

HR practices have a significant impact on organizational justice because the way that an employer behaves toward employees affects employee perceptions of justice (Fesharaki \& Sehhat, 2018). According to the social exchange theory (Blau, 1964), if organizations do not care for their employees - for instance, through their HR practices - these employees are likely to perceive that there is no reciprocity in the exchange relationship and will perceive this as unfair. Empirical evidence supports this relationship. For example, Pindek et al. (2017) suggested that job applicants perceive employment processes to be unfair if recruitment and selection are biased. Fesharaki and Sehhat (2018) showed how different HR practices (recruitment, selection, training, development, remuneration, compensation, and performance appraisal) were positively associated with organizational justice. Similarly, Wilton (2016) pointed to a positive relationship between training and development, appropriate remuneration, and organizational justice. Finally, Lee and Chui (2019) found a significant and positive relationship between compensation and benefits, work processes, training and development, and interactional justice.

In addition, drawing on social exchange theory (Blau, 1964) as an overarching framework, we suggest that organizational justice is a measure of reciprocity in the social exchange relationship between organizations and employees (Robinson, 1996). Employees are likely to assess their investments compared to their outcomes from the organization, as well as the quality and nature of their relationship with the organization (Festinger, 1954; Picccoli \& De Witte, 2015). In this respect, an incipient literature on the relationship between HR practices and organizational justice suggests that organizational justice can also mediate the effect of HR practices on employee outcomes (e.g., Lee \& Chui, 2019; Zhang \& Agarwal, 2009).

More specifically, Lee and Chui (2019, p. 130) contend that for HR practices to effectively contribute to organizational efficiency, management practices must be seen to be fair and to support work-related wellbeing. They argue that 
perceptions of fairness reflect the employees' interpretation of the treatment by the management. In their empirical study in a healthcare organization, they found that interactional justice positively mediates the relationship between HR practices (compensation, work processes, and training and development) and perceived organizational support. They contend that fair treatment and clear communication by the administration of HR determines employees' perceived organizational support, whereas negative feelings of interactional justice may adversely affect employees' attitudes and performance.

Another study found support that distributive, procedural and interactional justice can mediate the relationship between HR practices (empowerment, psychological contract fulfilment, and communication) and organizational citizenship behaviour and turnover intentions (Zhang \& Agarwal, 2009). These authors found that different HR practices influenced different types of organizational justice (e.g., communication influenced procedural and interactional justice). Furthermore, they found that the three dimensions of justice significantly influenced OCB and turnover intention, with the exception of the link between procedural justice and turnover intention which they attributed to cultural factors (i.e., 'guanxi', a concept describing interpersonal relationships).

Overall, according to social exchange theory (Blau, 1964), these studies propose that if organizations develop 'good' HR practices, which are interpreted by employees as fair at the distributive, procedural and personal levels, and understood as caring for them, then they should be associated with more positive employee reactions. Despite the significant insights provided by these studies, they did not examine wellbeing as a critical outcome of HR practices, and their HR practice measures reflect some very specific and limited aspects of HR practices. Our aim is to shed light on the relationship between a broader measure of HR practices and employee wellbeing mediated by organizational justice. We hypothesize as follows:

$H 2$. The relationship between HR practices and employee hedonic wellbeing is mediated by distributive justice $(\mathrm{H} 2 \mathrm{a})$, procedural justice $(\mathrm{H} 2 \mathrm{~b})$ and interactional justice $(\mathrm{H} 2 \mathrm{c})$.

H3. The relationship between HR practices and employee eudemonic wellbeing is mediated by distributive justice $(\mathrm{H} 3 \mathrm{a})$, procedural justice $(\mathrm{H} 3 \mathrm{~b})$ and interactional justice $(\mathrm{H} 3 \mathrm{c})$.

\section{The role of gender in HR practices}

The role of women has evolved over the years as a result of approaching equality between men and women, especially in the workplace. However, despite the progress made and global commitments to date, the perspectives of women in the world of work are far from being equal to those of men (Iris Lou et al., 2019). Women often have jobs with poorer conditions and lower wages than their male peers and, as well as facing greater difficulties in accessing employment (even precarious employment), once employed they face particular labour stressors that men do not have to face. According to Gyllensten and Palmer (2005), these stressors can be grouped as follows: (1) multiplicity of roles; (2) lack of progress in their professional career; and
(3) discrimination and stereotypes. It has been shown that the performance of women at work is usually attributed to factors that have nothing to do with their abilities. In addition, they are punished when they act in a way that does not fit the expectations associated with their gender (e.g., expressive and kind), yet they must behave in an individualistic way, focused on power, if they want to succeed professionally.

Regarding these working conditions for women, we can conclude that most are the responsibility of, or at least related to, HR practices. So, it seems plausible to suggest that gender plays a key role in HR practices within organizations. Mastracci and Arreola (2016) argue, according to the gender role theory, that no matter the proportions of women and men in organizations, gendered norms and practices maintain traditional roles for women and men, particularly regarding how and where women and men should work. As Perry (2010) pointed out, HR practices produce and reproduce outdated ideals and frustrate the efforts of all employees - women and men - to achieve gender equity.

Against the background of poorer conditions for women in the workplace and considering the gender role theory (Lin \& Billingham, 2014), it can be hypothesized that our mediation model is likely to be influenced by gender. Given expected differences between men and women in relation to how HR practices are perceived in terms of justice and how they affect employee wellbeing, we propose the following hypotheses:

$\mathrm{H} 4$. The relationship between HR practices and hedonic wellbeing through distributive justice $(\mathrm{H} 4 \mathrm{a})$, procedural justice $(\mathrm{H} 4 \mathrm{~b})$ and interactional justice $(\mathrm{H} 4 \mathrm{c})$ will be negatively stronger for women than for men.

$\mathrm{H} 5$. The relationship between HR practices and eudemonic wellbeing through distributive justice $(\mathrm{H} 4 \mathrm{a})$, procedural justice $(\mathrm{H} 4 \mathrm{~b})$ and interactional justice $(\mathrm{H} 4 \mathrm{c})$ will be negatively stronger for women than for men.

\section{Method}

\section{Sample}

Total population of this study was unknown so a non-probability sampling technique was adopted in which the convenience sampling technique was used. The sample included 1647 employees from 42 Spanish organizations, with $43 \%$ of the employees being men $(n=714)$ and $52 \%$ being women $(n=856)$, distributed into three age groups: younger than 35 years old $(26 \% ; n=432)$, $35-50$ years old $(55 \%$; $n=910)$, and over 50 years old $(16 \% ; n=259)$. Regarding their education level, $1 \%$ had no official educational qualification ( $n=20), 13 \%$ had primary education $(n=211), 37 \%$ had secondary education $(n=607)$ and $48 \%$ had a university degree $(n=753)$. Finally, mean employment tenure was 7 years (range $1-36$ years).

\section{Procedure}

Researchers contacted the HR managers of each organization to explain the purpose of the research and the main features of the questionnaire and to request their collabo- 
ration. Once they accepted to participate in the research, questionnaires were distributed among workers. Questionnaires were filled out in the workplace by the participants, on paper or in a tablet or online via a link. Researchers were available for clarifications. Anonymous and confidential treatment of the data was guaranteed. All employees who wished to participate were invited to do so. Given that we had to rely on voluntary participation, the sampling method could not be completely random.

\section{Measures}

HR practices were assessed with a self-developed 24item instrument based on previous research on relevant HR practices (Boon et al., 2011, Guest, 2017). The assessed practices were those considered as the main practices in the studies on HR practices (see Boon et al., 2011). Following Guest's $(2002,2017)$ recommendations, we included additional employee-centred HR practices that are related to employees' well-being (exit system, work-life balance, and security). Thus, our measure covered eight HR practices: training and development, contingent pay and rewards, performance appraisal, recruitment and selection, competitive salary, employment security, work-life balance, and exit system. Each HR practice was measured through 3 items. Despite this dimensionality, according to our research objective, we adopted a global measure of $\mathrm{HR}$ practices as done in previous studies (e.g., Findıkl et al., 2015; Mustafi et al., 2016). The overall constructs represented the overall organizational functions, strategies or processes (Morgeson \& Hofmann, 1999). A sample item was: "The organization offers me the opportunity to follow training, courses and workshops". The response scale ranged from 1 (not at all) to 5 (a lot). Cronbach's alpha for this scale was .93 .

Organizational justice in its 3 dimensions was measured on a 9-item scale by Colquitt (2001) as follows: distributive justice, (e.g., "To what extent the compensations (salary, incentives) you obtain in exchange for your work reflect the effort you have put into your work"); procedural justice, (e.g., "To what extent the procedures that affect you at work have been applied consistently?"); and interactional justice (e.g., "To what extent your immediate boss has treated you with respect?"). The response scale ranged from 1 (rarely or never) to 6 (very often). Cronbach's alphas for distributive, procedural and interactional justice were $.95, .74$ and .87 , respectively.

Hedonic wellbeing was measured using the reduced 10 item scale Job Satisfaction Scale (IJSS) by Cooper et al. (1989), which measures intrinsic motivation through 5 items (e.g., 'recognition you get for your good work') and extrinsic motivation through 4 items (e.g., 'your fellow workers') and one general satisfaction item ("What is your level of satisfaction with your job as a whole?"). Agreement with the items was rated on a Likert scale from 1 (very dissatisfied) to 7 (very satisfied). Cronbach's alpha for hedonic wellbeing was .87 .

Eudemonic wellbeing was measured through two subscales of psychological well-being (Ryff, 1989): purpose in life with 4 items (e.g., 'I try to improve or make important changes in my life') and personal growth with 4 items (e.g., 'I have a sense of direction and purpose in life'). Cronbach's alpha for eudemonic wellbeing was .72 .

\section{Analyses}

Preliminary analyses consisted of computing means, standard deviations and correlations. Confirmatory factor analyses were also computed to examine the validity of our measures. To test our hypotheses on the mediation effects of organizational justice and the hypothesized moderating effects of gender we used multi-group structural equation modelling (multi-group SEM; Byrne, 2010) and AMOS 18 (Arbuckle, 2009). We computed 2 nested models, namely a constrained and an unconstrained model. In the constrained model, all path coefficients and correlations were set to be equal in the men and women subsamples. In the unconstrained model, these parameters were allowed to vary between the two subsamples. Maximum likelihood was used to estimate the parameters of the model. For parameter estimation, the bootstrapping method was applied (Preacher \& Hayes, 2008). Also, Sobel's test was computed to examine the indirect effect of HR practices on life satisfaction for different dimensions of organizational justice in the men and women subsamples.

\section{Results}

Table 1 presents descriptive data variables for the total sample along with correlations, showing that most variables were significantly related.

Table 1 Descriptive analysis: means, standard deviations and intercorrelations

\begin{tabular}{|c|c|c|c|c|c|c|c|c|c|c|}
\hline & & Mean & $S D$ & 1 & 2 & 3 & 4 & 5 & 6 & 7 \\
\hline 1 & $\begin{array}{l}\text { Sex } \\
(0 \text { = female; } \\
1=\text { male })\end{array}$ & - & - & - & & & & & & \\
\hline 2 & $\begin{array}{l}\mathrm{HR} \\
\text { practices }\end{array}$ & 2.86 & .78 & $.07^{* *}$ & - & & & & & \\
\hline 3 & $\begin{array}{l}\text { Distributive } \\
\text { justice }\end{array}$ & 2.92 & 1.06 & $.10^{* *}$ & $.59^{* * *}$ & - & & & & \\
\hline 4 & $\begin{array}{l}\text { Procedural } \\
\text { justice }\end{array}$ & 3.14 & .88 & .04 & $.53^{* *}$ & $.41^{* *}$ & - & & & \\
\hline 5 & $\begin{array}{l}\text { Interactional } \\
\text { justice }\end{array}$ & 4.21 & .83 & $-.06^{*}$ & $.34^{* *}$ & $.31^{* *}$ & $.43^{* *}$ & - & & \\
\hline 6 & $\begin{array}{l}\text { Hedonic } \\
\text { wellbeing }\end{array}$ & 5.14 & .92 & -.01 & $.59^{* *}$ & $.57^{*^{*}}$ & $.50^{* * *}$ & $.52^{* *}$ & - & \\
\hline 7 & $\begin{array}{l}\text { Eudemonic } \\
\text { wellbeing }\end{array}$ & 5.78 & .75 & $-.13^{* *}$ & $.11^{* *}$ & .02 & $.16^{* *}$ & $.16^{* *}$ & $.28^{* *}$ & - \\
\hline
\end{tabular}

Note. ${ }^{*} p<.05,{ }^{* *} p<.01$

Table 2 presents the multi-group SEM results and the CFA results for our measures. Results evidence a good fit for all our measures: Three structural models for HR practices were examined: one-global factor structure, 8-factor structure and a second-order factor structure. The 3 models appropriately fit the data with similar fit indexes (see Table 2), indicating similar results to those reported by Boon et al. (2011). In methodological terms, therefore, it was possible to measure HR practices through these 3 factor models. However, following to Morgeson and Hofmann (1999), and 
taking into account our research objective, the one-factor solution was used in this work; thus, we could examine the overall perception of organizational functions, strategies or processes in HR practices. To corroborate the 3-dimensions structure of organizational justice, two models were examined: one-global factor and three-factors model. Results showed that 3-dimensions model presented better fit than the one-factor solution. Finally, hedonic and eudemonic wellbeing structure were examined by comparing one-global solution and two-dimension structure. Results showed a better fit for the one-factor model for hedonic well-being and the one-factor solution for eudemonic well-being. Hence, we could conclude that our variables presented appropriate validity.

Regarding multi-group SEM results, the unconstrained multi-group model fitted the data very well and significantly better than the constrained model (see Table 2; $\left.\Delta \mathrm{x}^{2}=488.47, d f=1, p<.01\right)$. In fact, the constrained model which did not take the gender variable into account did not fit the data appropriately, indicating that at least some of the structural parameters differed significantly between the two subsamples of men and women.

Figure 1 displays results of hypothesized relationships. Results partially support $\mathrm{H} 1$ in regard to the relationship between HR practices and wellbeing. A significant and positive relationship was found between HR practices and hedonic wellbeing $(\mathrm{H} 1 \mathrm{a})$, whereas the relationship between HR practices and eudemonic wellbeing was non-significant (H1b).

$\mathrm{H} 2$, which established the mediation effect of organizational justice, was confirmed, as results showed a significant and positive relationship between HR practices and organizational justice (distributive, procedural and interactional justice) in the men and women subsamples. In addition, a significant link was found for organizational justice (distributive, procedural and interactional) with hedonic wellbeing in both subsamples. The indirect effect of $\mathrm{HR}$ practices on hedonic wellbeing via the 3 organizational justice dimensions was significant in the men subsample (distributive justice, Sobel's $z=-9.86 p<.05$; procedural justice, Sobel's $z=5.17, p<.05$; interactional justice, Sobel's $z=8.24, p<.05$ ) and in the women subsample (distributive justice, Sobel's $z=10.08, p<.05$; procedural justice, Sobel's $z=3.28, p<.05$; interactional justice, Sobel's $z=7.53, p<.05)$.

$\mathrm{H} 3$, referring to the mediation effect in the relationship between HR practices and eudemonic wellbeing, was also supported. The indirect effect of HR practices on eudemonic wellbeing via organizational justice was also significant in both the men subsample (distributive justice, Sobel's $z=-1.99, p<.05$; procedural justice, Sobel's $z=4.24, p<.05$; interactional justice, Sobel's $z=2.93, p<.05$ ) and the women subsample (distributive justice, Sobel's $z=-3.46, p<.05$; procedural justice, Sobel's $z=2.31, p<.05$; interactional justice, Sobel's $z=1.64, p<.01)$. Finally, the results also showed a significant relationship between organizational justice and hedonic well-being. However, the results showed that the relationship between organizational justice and eudemonic wellbeing varied in significance depending on the subsample. Procedural justice was significantly and positively related to eudemonic wellbeing in both subsamples. However, the relationship between distributive justice and eudemonic wellbeing was only significant for women, whereas the relationship between interactional justice and eudemonic wellbeing was only significant for men.

In contradiction to $\mathrm{H} 4$ and $\mathrm{H} 5$, we did not identify stronger effects in women than in men, as the effect of HR practices on hedonic and eudemonic wellbeing through organizational justice were stronger in men.

\section{Discussion}

Although literature on HR practices has attracted much research, further development of the relationships of HR practices with other variables is necessary (Guest, 2011, 2017).

Table 2 Fit indices for CFAs and SEMs

\begin{tabular}{|c|c|c|c|c|c|c|c|c|}
\hline & $\chi^{2}$ & df & $p$ & $\chi^{2 / d f}$ & NFI & IFI & CFI & RMSEA \\
\hline CFA: HR practices - 1 factor & 1486.02 & 228 & .00 & 6.52 & .94 & .95 & .95 & .058 \\
\hline CFA: HR practices - 2 factors & 2194.16 & 224 & .00 & 9.79 & .91 & .92 & .92 & .073 \\
\hline CFA: HR practices - second order & 2493.99 & 244 & .00 & 10.22 & .90 & .91 & .91 & .075 \\
\hline CFA: Organizational justice - 1 factor & 3468.98 & 27 & .00 & 128.48 & .64 & .64 & .64 & .278 \\
\hline CFA: Organizational justice - 3 factors & 725.86 & 27 & .00 & 26.88 & .92 & .93 & .93 & .125 \\
\hline CFA: Hedonic well-being- 1 factor & 471.18 & 33 & .00 & 14.27 & .93 & .94 & .94 & .090 \\
\hline CFA: Hedonic well-being- 2 factors & 2116.80 & 36 & .00 & 58.8 & .69 & .69 & .69 & .187 \\
\hline CFA: Eudemonic well-being- 1 factor & 200.57 & 19 & .00 & 10.55 & .91 & .92 & .92 & .076 \\
\hline CFA: Eudemonic well-being- 2 factors & 975.08 & 20 & .00 & 48.75 & .58 & .59 & .59 & .170 \\
\hline CFA: Well-being- 1 global factor & 2717.94 & 119 & .00 & 22.83 & .69 & .70 & .70 & .115 \\
\hline $\begin{array}{l}\text { Multi-group SEM: structural model (with controls) } \\
\text { - constrained }\end{array}$ & 181.00 & 4 & .00 & 45.25 & .94 & .94 & .94 & .164 \\
\hline $\begin{array}{l}\text { Multi-group SEM: structural model (with controls) } \\
\text { - unconstrained }\end{array}$ & 50.78 & 4 & .00 & 12.69 & .98 & .98 & .98 & .087 \\
\hline
\end{tabular}

Notes. $\chi^{2}=$ chi-square discrepancy; $\mathrm{df}=$ degrees of freedom; $\chi^{2} / \mathrm{df}=$ relative chi-square; IFI =incremental fit index; TLI =Tucker Lewis index; $\mathrm{CFI}=$ comparative fit index; RMSEA =root mean square error of approximation; ${ }^{* *} p<.01,{ }^{*} p<.05$; ${ }^{\text {a }}$ equal path coefficients and covariances in both subsamples; ${ }^{b}$ different path coefficients and covariances in both subsamples. 
(HW) W: .25**

$M: .29^{* *}$

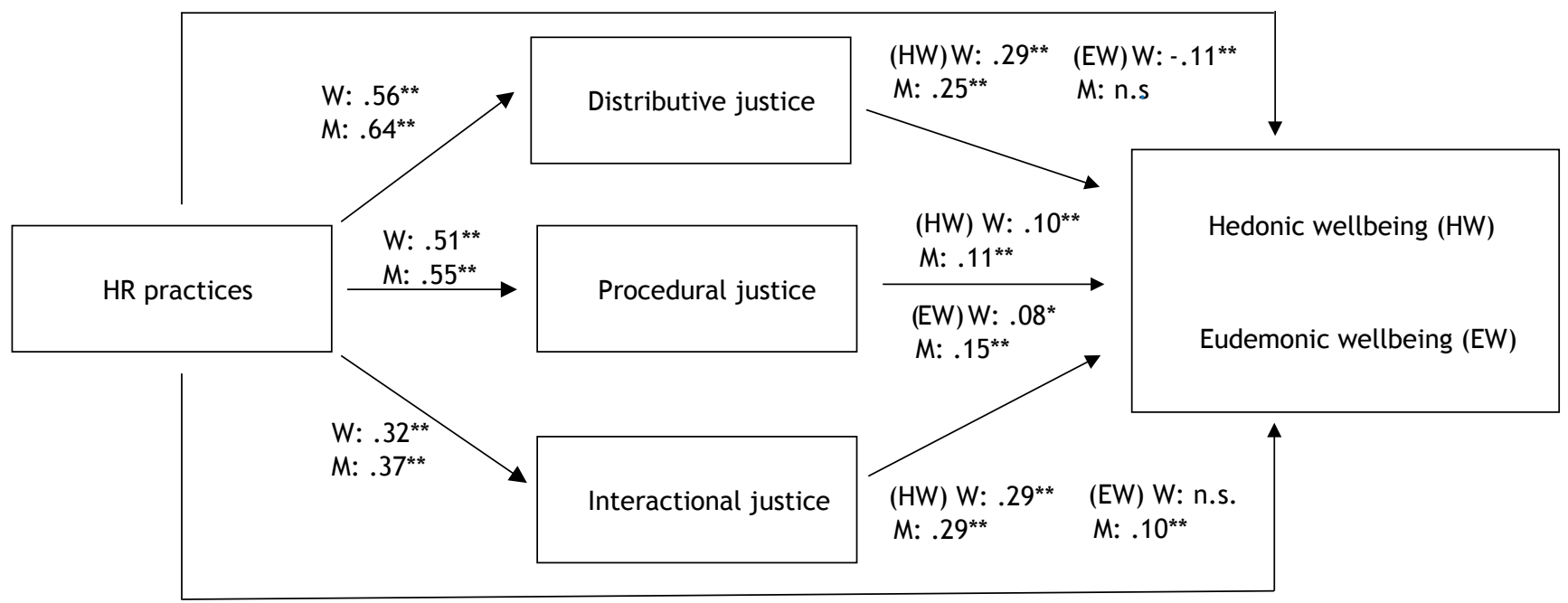

(EW) W: n.s.

M: n.s.

Figure 1. Results of multi-group SEM (unconstrained) for men $(M)$ and women (W) subsamples

Notes. All parameters are standardized; ${ }^{* *} p<.01,{ }^{*} p<.05$

Some authors point out the need to continue studying the relationship between HR practices and employee well-being (e.g., Kowalski \& Loretto, 2017). Hence, the aim of this study was to examine the relationship between HR practices and well-being (eudemonic and hedonic), and explore the mediating role of organizational justice, taking gender differences into account.

In this way, our study contributes to previous research on HR practices in several aspects. First, we found support for a direct relationship between HR practices and hedonic wellbeing. Thus, our results support the social exchange hypothesis (Blau, 1964) in showing that 'good' HR practices ensure a positive exchange relationship between organizations and employees; employees perceive that their organizations value their contributions and care for their wellbeing, and therefore feel comfortable within their organizations. Our results are congruent with previous research on HR practices that suggests a link between HR practices and wellbeing (Guest, 2011; Guest, 2017; Peccei, 2004). On the other hand, the direct relationship between HR practices and eudemonic wellbeing was not significant. According to these results, good HR practices per se are not related to employees' wellbeing in relation to pursuing excellence, growth and meaning in one's life.

Second, given that the relationship between HR practices and wellbeing does not seem to be clear in previous research, it is important to identify and analyse some variables that may affect this relationship. One of these variables is organizational justice because, as Heffernan and Dundon (2016) stated, justice perceptions affect employees' responses to HR practices. The second contribution of our study is providing empirical evidence that organizational justice plays a vital role in the relationship between HR practices and psychological wellbeing. We found empirical evidence supporting the mediation of HR practices through the three dimensions of organizational justice to predict hedonic wellbeing in both subsamples, and four significant paths out of six to predict eudemonic wellbeing. Our results support the social exchange hypothesis and shed light on mechanisms responsible for the impact of HR practices on employee wellbeing. Organizational justice may be perceived by employees as a signal of reciprocity in their exchange relationship with their organizations. These results are also congruent with previous studies (e.g., Jiang et al. 2012) and support the incipient research that points to organizational justice as a mediator (e.g., Lee \& Chui, 2019; Zhang \& Agarwal, 2009).

Third, HR practices are related to inequalities (Stamarski \& Son Hin, 2015). Hence, we proposed to examine the role of gender in the association with HR practices and well-being mediated by organizational justice. We found results that contradict our initial hypothesis. We assumed stronger effects for women because of their poorer working conditions and job opportunities, but our data showed the opposite. A possible explanation is to be found in the "justice paradox" (Crosby, 1982; Mueller \& Wallace, 1996). Justice evaluation involves a social comparison of one's own situation with that of others, but this comparison is done with individuals similar to oneself. Thus, it may occur that female workers are satisfied with less than male workers because they compare themselves, not to men, but to other female workers when assessing justice. Given that other women also work in poor conditions; they perceive their situation as just because their conditions are similar to those of other women. Studying the mechanisms explaining the stronger effects in the women subsample is undoubtedly an interesting direction for future research.

\section{Limitations}

Despite the insights of this research, it also presented some limitations. The cross-sectional design did not allow 
for an assessment of causality, which means that causal relationships among the independent and dependent variables cannot be concluded. Longitudinal studies are necessary to examine causality or changes over time in those relationships. Furthermore, our data collection method was based on a convenience sampling. This method may limit the extrapolation of results. However, as in other works (e.g., Bakker et al., 2019), it is not likely that this threatens the validity of our results. It seems more probable that the studied variables and their relationships are similar in other samples. Finally, our variables were self-reported measures, which points to the possibility that our results are affected by common method variance. However, it is important to note that variables such as well-being are variables which are focused on individual feelings, so it is complex that these feelings can be evaluated with the same precision from other sources. However, future research should consider including other external or more objective sources of data, such as the employer as a source for HR practices.

\section{Future Research}

One avenue for future research is to continue examining social exchange as a framework for understanding the motivational underpinnings of employee work attitudes and behaviours. We examined wellbeing, but multiple and additional outcomes could be related to HR practices. On the other side, we have measured HR practices with a global measure. It is important to explore in future research whether it is preferable to take this global measure or on the contrary, analyse whether different dimensions will affect different variables unequally. It is important for HR managers to identify if some practices have more weight than others in leading to perceptions of justice, to different types of well-being, or affect men and women differently.

Our results found in general a weaker relationship between HR practices and eudemonic well-being than with hedonic wellbeing. It would be important to identify and explore which HR practices may be more related to eudemonic well-being, such as those that help balance work-life. Likewise, as mentioned above, it is important to investigate whether the obtained results about gender are due to the fact that women have adopted other women as the reference group or if other mechanisms play a part. Finally, in this study we have analysed HR practices and the different types of justice. It would be interesting to address the study of new antecedents of well-being, and relevant consequences such as performance or intention to quit. Besides, it would be interesting for future research to analyse whether the two types of well-being (hedonic and eudemonic) have different consequences for workers.

\section{Theoretical and practical implications}

The present study contributes to the literature by (1) providing empirical evidence on the effect of HR practices on employees' well-being, (2) showing how employees' perceptions of organizational justice mediate the association between HR practices and well-being, and (3) demonstrating how gender may differently affect employees' well-being as a function of their HR practices and organizational justice perceptions. It confirmed the critical role of gender in HR practices.

This study also presents practical implications. For companies to be able to maintain high levels of well-being among their workers, it is important to identify which variables influence well-being. Our results evidence the need for organizations to adopt "good" HR practices that not only promote employees' performance but also enhance their well-being within organizations. Likewise, organizational justice, in its three dimensions, was also critical to maintain employees' well-being. In other words, HR managers should promote not only fair retributions or rewards, but also fair organizational processes and treatment for their employees, in order to promote employees' well-being.

Human resource practices and organizational justice offer tools to HR managers on how to act in order to maintain and improve well-being levels. Hence, one critical recommendation for those HR managers who wish to promote and guarantee their employees' well-being, is that they develop and apply "good" HR practices as well as ensure that their employees perceive organizations as fair in terms of retribution, processes, and interactions.

\section{Conclusion}

This study contributes to the current understanding of the link between HR practices and well-being, showing the positive relationship between them. HR practices had a direct effect on hedonic wellbeing, and a mediated through justice effect on both hedonic and eudemonic wellbeing. This confirms the importance of organizational justice, as a mediator between organizational HR-practices and employees' well-being. Furthermore, it provides evidence on the importance of considering gender in order to shed light on differential relationships between the study variables.

\section{Funding}

This research is co-financed by the European Regional Development Fund (ERDF), whereby the beneficiaries, in all projects, shall publicize the aid received in the service and labour contracts, publications and other results of the research, papers, inventories and results dissemination activities financed by the Ministry of Economy and Competitiveness and the European Regional Development Fund (ERDF) as funding bodies.

\section{References}

Adams, J. S. (1965). Inequity in social exchange. In L. Berkowithz (Ed.), Advances in Experimental Social Psychology (Vol. 2, pp. 267-299). Academic Press.

Arbuckle, J. L. (2009). Amos 18 user's guide. Amos Development Corporation.

Aryee, S., Budhwar, P. S., \& Chen, Z. X. (2002). Trust as a mediator of the relationship between organizational justice and work outcomes: Test of a social exchange model. Journal of Organizational Behaviour, 23, 267-285. https://doi.org/10.1002/job.138 
Bakker, A. B., Sanz-Vergel, A. I., Rodríguez-Muñoz, A., \& Antino, M. (2019). Ripple effects of surface acting: A diary study among dual-earner couples. Spanish Journal of Psychology, 22, e7. https://doi.org/10.1017/sjp.2019.6

Blau, P. (1964). Exchange and power in social life. Wiley.

Boon, C., Den Hartog, D. N., Boselie, P., \& Paauwe, J. (2011). The relationship between perceptions of HR practices and employee outcomes: Examining the role of person-organisation and person-job fit. The International Journal of Human Resource Management, 22, 138-162. https://doi.org/10.1080/ 09585192.2011 .538978

Byrne, B. M. (2010). Structural equation modelling with AMOS: Basic concepts, applications, and programming (2nd ed.), Psychology Press.

Cohen-Charash, Y., \& Spector, P. E. (2001). The role of justice in organizations: A meta-analysis. Organizational Behaviour and Human Decision Processes, 86(2), 278-321.

Colquitt, J. A. (2001). On the dimensionality of organizational justice: A construct validation of a measure. Journal of Applied Psychology, 86, 386-400. https://doi.org/10.1037/00219010.86.3.386

Cooper, C. L., Rout, U., \& Faragher, B. (1989). Mental Health, Job Satisfaction, and Job Stress Among General Practitioners. British Medical Journal, 298, 366-370.

Crosby, F. (1982). Relative Deprivation and Working Women. Oxford University Press.

Culbertson, S. S., Fullagar, C. J., \& Mills, M. J. (2010). Feeling good and doing great: The relationship between psychological capital and well-being. Journal of Occupational Health Psychology, 15, 421-433. https://doi.org/10.1037/a0020720

Diener, E. (2000). Subjective well-being: The science of happiness and a proposal for a national index. American Psychologist, 55, 34-43. https://doi.org/10.1037/0003-066x.55.1.34

Diener, E., Oishi, S., \& Lucas, R. E. (2003). Personality, culture, and subjective well-being: Emotional and cognitive evaluations of life. Annual Review of Psychology, 54, 403-25. https://doi. org/10.1146/annurev.psych.54.101601.145056

Fesharaki, F., \& Sehhat, S. (2018). Islamic human resource management (iHRM) enhancing organizational justice and employees' commitment: A case of a Qard Al-Hasan bank in Iran. Journal of Islamic Marketing, 9, 204-218. https://doi.org/10.1108/jima03-2017-0029

Festinger, L. (1954). A theory of social comparison processes. Human Relations, 7(2), 117-140.

Findıklı, M. A., Yozgat, U., \& Rofcanin, Y. (2015). Examining organizational innovation and knowledge management capacity the central role of strategic human resources practices (SHRPs). Procedia-Social and Behavioural Sciences, 181, 377387. https://doi.org/10.1016/j.sbspro.2015.04.900

Folger, R., \& Cropanzano, R. (1998). Organizational Justice and Human Resource Management. Sage.

Gould-Williams, J., \& Davies, F. (2005). Using social exchange theory to predict the effects of HRM practice on employee outcomes. Public Management Review, 7, 1-24. https://doi.org $/ 10.1080 / 1471903042000339392$

Guest, D. E. (2002). Human resource management, corporate performance and employee wellbeing: Building the worker into HRM. Journal of Industrial Relations, 44, 335-358. https://doi. org/10.1111/1472-9296.00053

Guest, D. E. (2011). Human resource management and performance: Still searching for some answers. Human Resource Management Journal, 21, 3-13. https://doi.org/10.1111/j.17488583.2010.00164.x

Guest, D. E. (2017). Human resource management and employee well-being: Towards a new analytic framework. Human Resource Management Journal, 27, 22-38. https://doi. org/10.1111/1748-8583.12139
Guest, D. E., \& Peccei, R. (2001). Partnership at work: Mutuality and the balance of advantage. British Journal of Industrial Relations, 39, 207-236. https://doi.org/10.1111/1467-8543.00197

Gyllensten, K., \& Palmer, S. (2005). The role of gender in workplace stress: A critical literature review. Health Education Journal, 64, 271-288. https://doi.org/10.1177/001789690506400307

Heffernan, M., \& Dundon, T. (2016). Cross-level effects of high-performance work systems (HPWS) and employee well-being: The mediating effect of organisational justice. Human Resource Management Journal. 26(2), 211-231. https://doi. org/10.1111/1748-8583.12095

Iris Lou, X., Schleifer, C., \& Hill, C. M. (2019). Police income and occupational gender inequality. Police Quarterly, 22, 481-510. https://doi.org/10.1177/1098611119862654

Jalalkamali, M., Ali, A. J., Hyun, S. S., \& Nikbin, D. (2016). Relationships between work values, communication satisfaction, and employee job performance: The case of international joint ventures in Iran. Management Decision, 54, 796-814. https:// doi.org/10.1108/md-01-2015-0003

Jiang, K., Lepak, D., Hu, J., \& Baer, J. (2012). How does human resource management influence organizational outcomes? A meta-analytic investigation of mediating mechanisms. Academy of Management Journal, 55, 1264-1294. https://doi.org/10.5465/ amj.2011.0088

Kariithi, J. W., \& Odongo, M. (2016). Impact of strategic human resource management practices on organizational performance (a case study of Safaricom). Human Resource and Leadership Journal, 1(1), 1-18.

Keenoy, T., \& Anthony, P. (1992). HRM: Metaphor, meaning and morality. In P. Blyton \& P. Turnbull (Eds.), Reassessing Human Resource Management (pp. 233-255). Sage.

Khilji, S. E., \& Wang, X. (2006). Intended and implemented HRM: The missing linchpin in strategic human resource management research. The International Journal of $\mathrm{Hu}$ man Resource Management, 17, 1171-1189. https://doi. org/10.1080/09585190600756384

Kowalski, T. H. P., \& Loretto, W. (2017). Well-being and HRM in the changing workplace. The International Journal of Human Resource Management, 28(16), 2229-2255. https://doi.org/10.1080/ 09585192.2017.1345205

Landsbergis, P., Cahill, J., \& Schnall, P. (1999). The impact of lean production and related new systems of work organization on worker health. Journal of Occupational Health Psychology, 4, 108-130. https://doi.org/10.1037/1076-8998.4.2.108

Lee, H., \& Chui, J. (2019). The mediating effect of interactional justice on human resource practices and organizational support in a healthcare organization. Journal of Organizational Effectiveness: People and Performance, 6, 129-144. https:// doi.org/10.1108/joepp-10-2018-0085

Legge, K. (2005). Human resource management: Rhetorics and realities. Palgrave Macmillan.

Lin, Y. C., \& Billingham, R. E. (2014). Relationship between parenting styles and gender role identity in college students. Psychological Reports, 114, 250-271. https://doi.org/10.2466/21.09. pr0.114k13w4

Mastracci, S., \& Arreola, V. I. (2016). Gendered organizations: How human resource management practices produce and reproduce administrative man. Administrative Theory \& Praxis, 38, 137149. https://doi.org/10.1080/10841806.2015.1130523

Messersmith, J. G., Patel, P. C., \& Lepak, D. P. (2011). Unlocking the black box: Exploring the link between high-performance work systems and performance. Journal of Applied Psychology, 96, 1105-1118. https://doi.org/10.1108/hrmid.2012.04420caa.007

Morgeson, F., \& Hofmann, D. A. (1999). The structure and function of collective constructs: Implications for multilevel research and theory development. The Academy of Management Review, 24, 249-265. https://doi.org/10.2307/259081 
Mueller, C. W., \& Wallace, J. E. (1996). Justice and paradox of the contented female worker. Social Psychology Quarterly, 59(4), 338-349. https://doi.org/10.2307/2787075

Mustafi, M. A. A., Rahman, T., \& Jahan, N. (2016). Human resource management (HRM) practices of the banking sector in Bangladesh: A study on private commercial bank. Asian Business Review, 6, 141-150. https://doi.org/10.18034/abr.v6i3.39

Peccei, R. (2004). Human resource management and the search for the happy workplace. Inaugural Address of Erasmus Research Institute of Management. Erasmus University Rotterdam.

Peiró, J. M., Ayala, Y., Tordera, N., Lorente, L., \& Rodríguez, I. (2014). Sustainable well-being at work: A review and reformulation. Papeles del Psicólogo, 35(1), 5-14.

Perry, J. L. (2010). A strategic agenda for public human resource management research. Review of Public Personnel Administration, 30, 20-43. https://doi.org/10.1177/0734371x09351821

Peterson, C., Park, N., \& Seligman, M. E. P. (2005). Orientations to happiness and life satisfaction: The full life versus the empty life. Journal of Happiness Studies, 6, 25-41. https://doi. org/10.1007/s10902-004-1278-z

Piccoli, B., \& De Witte, H. (2015). Job insecurity and emotional exhaustion: Testing psychological contract breach versus distributive injustice as indicators of lack of reciprocity. Work \& Stress, 29, 246-263. https://doi.org/10.1080/02678373.2015. 1075624

Pindek, S., Kessler, S. R., \& Spector, P. E. (2017). A quantitative and qualitative review of what meta-analyses have contributed to our understanding of human resource management. Human Resource Management Review, 27(1), 26-38. https://doi. org/10.1016/j.hrmr.2016.09.003

Preacher, K. J., \& Hayes, A. F. (2008). Asymptotic and resampling strategies for assessing and comparing indirect effects in multiple mediator models. Behaviour Research Methods, 40, 879891. https://doi.org/10.3758/BRM.40.3.879
Robinson, S. L. (1996). Trust and breach of the psychological contract. Administrative Science Quarterly, 41(4), 574-599.

Ryan, R., \& Deci, E. (2001). On happiness and human potentials: A review of research on hedonic and eudaimonic well-Being. Annual Review of Psychology, 52, 141-166. https://doi. org/10.1146/annurev.psych.52.1.141

Ryff, C. D. (1989). Happiness is everything, or is it? Explorations on the meaning of psychological well-being. Journal of Personality and Social Psychology, 57, 1069-1081.

Stamarski, C. I., \& Son Hing, L. (2015) Gender inequalities in the workplace: The effects of organizational structures, processes, practices, and decision makers' sexism. Frontiers in Psychology, 6, 1400. https://doi.org/10.3389/fpsyg.2015.01400

Sun, L., Aryee, S., \& Law, K. S. (2007). High-performance human resource practices, citizenship behaviour, and organizational performance: A relational perspective. Academy of Management Journal, 50, 558-577. https://doi.org/10.5465/ amj.2007.25525821

Valizade, D., Ogbonnaya, C., Tregaskis, O., \& Forde, C. (2016). A mutual gains perspective on workplace partnership: Employee outcomes and the mediating role of the employment relations climate. Human Resource Management Journal, 26, 351-368. https://doi.org/10.1111/1748-8583.12113

Wilton, N. (2016). An introduction to human resource management. Sage.

Wright, P. M., \& Nishii, L. H. (2006). Strategic HRM and organizational behaviour: Integrating multiple levels of analysis. In J. Paauwe, D. E. Guest \& P. M. Wright (Eds.), HRM and performance: Achievements and challenges (pp. 97-111). Wiley

Zhang, H., \& Agarwal, N. C. (2009). The mediating roles of organizational justice on the relationships between HR practices and workplace outcomes: An investigation in China. International Journal of Human Resource Management, 20, 676-693. https:// doi.org/10.1080/09585190802707482 